\title{
Editorial
}

\section{Psicologia Escolar e Educacional na América Latina}

O II Congresso de Psicologia da União Latino-Americana de Psicologia (ULAPSI) aconteceu em setembro de 2007 em Cuba com grande participação de psicólogos brasileiros. A temática do Congresso foi a psicologia latino-americana para os psicólogos latino-americanos, possibilitando, por meio das discussões e trabalhos apresentados, a consolidação de uma Psicologia para as necessidades e características da América Latina.

A Psicologia Escolar e Educacional revelou sua identidade brasileira e buscou construir uma latino-americana, pela apresentação de muitos trabalhos com colegas de vários países. Isto resultou em intercâmbios profissionais e de pesquisa visando estreitar os laços com nossos parceiros na América Latina.

Estabeleceram-se parcerias que possibilitaram a organização de um Grupo de Trabalho em Psicologia Educacional cuja meta principal é produzir referências latino-americanas para os profissionais que atuam na área. Definiu-se, também, pela organização de um número especial dedicado à Psicologia Escolar na revista Psicología para a América Latina publicada pela ULAPSI a fim de sintetizar e dar visibilidade às ações tanto no âmbito da pesquisa quanto às relativas aos profissionais nesta área.

Isto posto, cabe considerar que tal avanço deve-se, especialmente, ao próprio desenvolvimento da Associação Brasileira de Psicologia Escolar e Educacional (ABRAPEE) que tem, desde sua fundação, crescido e se colocado como parceira dos profissionais, conquistando espaço de atuação nos contextos de aprendizagem. Manter-se vinculado à ABRAPEE é participar deste movimento pró-educação e aprendizagem, no qual a prevenção é a palavra de ordem.

Lembro que em abril de 2008 ocorrerão as eleições para uma nova diretoria realizar a gestão da ABRAPEE para o biênio 2008 - 2010. Comprometer-se com a Psicologia Escolar e Educacional também significa participar ativamente do processo eleitoral - votando e sendo votado. Cabe-nos, a cada um e a todos, atender a este chamamento pela Psicologia Escolar e Educacional Brasileira e Latino-americana.

Maria Cristina Rodrigues Azevedo Joly Editora 